\title{
Understanding Human and Ecosystem Dynamics in the Kola Arctic: A Participatory Integrated Study
}

\author{
ALEXEY VOINOV $, 1,2$ LARS BROMLEY,${ }^{3}$ ELIZABETH KIRK, ${ }^{3}$ ANATOLIY KORCHAK,${ }^{4}$ JOSHUA FARLEY, \\ TATIANA MOISEENKO, ${ }^{5}$ TATIANA KRASOVSKAYA,${ }^{6}$ ZOYA MAKAROVA,${ }^{7}$ VLADIMIR MEGORSKI, ${ }^{7}$ \\ VLADIMIR SELIN,${ }^{4}$ GALINA KHARITONOVA ${ }^{4}$ and ROBERT EDSON ${ }^{8}$
}

(Received 18 June 2003; accepted in revised form 26 July 2004)

\begin{abstract}
The Lake Imandra watershed is located in one of the most developed regions in the Arctic-the Kola Peninsula of Russia. Approximately 300000 people live on the roughly $27000 \mathrm{~km}^{2}$ watershed, making it one of the most densely populated areas of the Arctic. Most of the people are involved in large-scale mineral extraction and processing and the infrastructure needed to support this industry. This paper reports the results of a pilot project staged for the Lake Imandra watershed that has put human dynamics within the framework of ecosystem change to integrate available information and formulate conceptual models of likely future scenarios. The observation period is one of both rapid economic growth and human expansion, with an overall economic decline in the past decade. We are applying the Participatory Integrated Assessment (PIA) approach to integrate information, identify information gaps, generate likely future scenarios, and link scientific findings to the decision-making process. We found an increasingly vulnerable human population in varying states of awareness about their local environment and fully cognizant of their economic troubles, with many determined to attempt maintenance of relatively high population densities in the near future even as many residents of northern Russia migrate south. A series of workshops have involved the citizens and local decision makers in an attempt to tap their knowledge of the region and to increase their awareness about the linkages between the socioeconomic and ecological components.
\end{abstract}

Key words: watershed analysis, Kola, ecological economics, adaptive management, development scenarios

RÉSUMÉ. Le bassin hydrographique du lac Imandra est situé dans l'une des régions les plus développées de l'Arctique, soit la presqu'île de Kola, en Russie. Près de 300000 personnes vivent dans la zone du bassin qui couvre environ 27000 km², ce qui en fait l'une des régions les plus peuplées de l'Arctique. La plupart des habitants travaillent dans l'extraction et le traitement miniers à grande échelle ainsi que dans l'infrastructure qui soutient cette industrie. Le présent article rapporte les résultats d'un projet pilote mis sur pied pour le bassin du lac Imandra, projet qui a placé la dynamique humaine dans le cadre du changement des écosystèmes, afin d'intégrer l'information disponible et de formuler des modèles conceptuels de scénarios probables dans l'avenir. La période d'observation en est une à la fois de croissance économique et d'expansion démographique rapides, suivie d'un déclin général au cours de la dernière décennie. On a recours à la méthode d'évaluation participative intégrée (EPI) pour intégrer l'information, y dégager des lacunes, générer des scénarios probables dans l'avenir et établir un lien entre résultats de la recherche et processus décisionnel. On a trouvé qu'il y avait une population humaine de plus en plus vulnérable qui était sensibilisée à divers degrés aux problèmes locaux de l'environnement et pleinement consciente des difficultés économiques, population dont une bonne part était fermement décidée à tenter de maintenir à brève échéance des densités de population relativement élevées, alors même que les résidents du nord de la Russie migrent en grand nombre vers le Sud. On a tenu une série d'ateliers avec citoyens et décideurs locaux pour chercher à capter leurs connaissances de la région et à accroître leur sensibilisation aux liens existant entre les composantes socio-économiques et écologiques.

Mots clés: analyse du bassin hydrographique, Kola, écolo-économie, gestion adaptative, scénarios de mise en valeur

Traduit pour la revue Arctic par Nésida Loyer.

${ }^{1}$ Gund Institute for Ecological Economics, University of Vermont, 590 Main Street, Burlington, Vermont 05405-0088, U.S.A.

${ }^{2}$ Corresponding author: alexey.voinov@uvm.edu

${ }^{3}$ American Association for the Advancement of Science, 1200 New York Avenue, NW, Washington, D.C. 20005, U.S.A.

${ }^{4}$ Institute for Economic Problems, Russian Academy of Sciences, Kola Science Center, 14 Fersman Street, Apatity, Murmansk, 184200 Russia.

${ }^{5}$ Institute for Water Problems, Russian Academy of Sciences, Kola Science Center, 14 Fersman Street, Apatity, Murmansk, 184200 Russia.

${ }^{6}$ Geography Department, Moscow State University, Main Building, Vorobjovy Gory, Moscow 119899, Russia.

${ }^{7}$ Institute for Northern Ecological Problems, Russian Academy of Sciences, Kola Science Center, 14 Fersman Street, Apatity, Murmansk 184200, Russia.

${ }^{8}$ Center for Energy and Environmental Research, Altarum, 901 South Highland Street, Arlington, Virginia 22204, U.S.A.

(C) The Arctic Institute of North America 


\section{INTRODUCTION}

Baseline research on pristine Arctic ecosystems can benefit from studies on human-dominated Arctic ecosystems to improve understanding of possible development scenarios and enable alternative and adaptive strategies for sustainably managing resources (AMAP, 1998). Further, research on human and ecosystem dynamics in the Arctic may have a broader impact, bearing in mind the uncertainties of global change. Arctic habitats provide livelihoods that may be considered extreme. Studying and understanding these extremes, and learning how people adapt to change when the domains for adaptation are limited, should make us better prepared for "worst-case" scenarios.

Located in the northwest of Russia and bordering Finland, the Russian Kola Peninsula (Fig. 1) is a human-dominated Arctic ecosystem. It offers scientists a potential future scenario for the Arctic, as well as a laboratory for documenting the resilience of Arctic ecosystems under the pressures of intense industrialization. The dynamics of the post-Soviet economy and social structure create unique management and civil-sector challenges. Thus, the Kola Peninsula represents an outer boundary of environmental and Arctic system science. Given that large amounts of oil, gas, and minerals are present throughout the Arctic and likely to be exploited, a better understanding of altered Kola Peninsula ecosystems can help us to avoid repeating past mistakes.

\section{The Project}

Integrated socioeconomic and ecological analysis, started in 2001, is being conducted in the Lake Imandra basin of the Russian Kola Peninsula. The basin is a heavily, though patchily, industrialized watershed of about $27000 \mathrm{~km}^{2}$. It has economic value to the humans, who also take advantage of the ecosystem services that it provides: purifying water for human consumption and agricultural use, long-term carbon sequestering, fixing of nutrients and contaminants in the soil and vegetation, erosion prevention, water filtration, and food. Attempts are being made to provide some qualitative and quantitative assessment of the value of such ecosystem goods and services worldwide (Costanza, 1996; Costanza et al., 1997), but little is known about Arctic ecosystems in this regard. In the Russian North in particular, society is certainly in flux (the preliminary results of the 2002 census give clear evidence of vast migration of people from the north and east of the country towards the center and south). This instability makes valuation of resources even more difficult, as actual ownership and stewardship of the environment itself are in transition. These trends are likely to continue and are considered as one of the scenarios in our analysis. Our project applies a participatory approach that incorporates local stakeholders into the research process.

Partners in this pilot project are the Kola Science Center of the Russian Academy of Sciences, the Gund Institute for Ecological Economics at the University of Vermont, and the

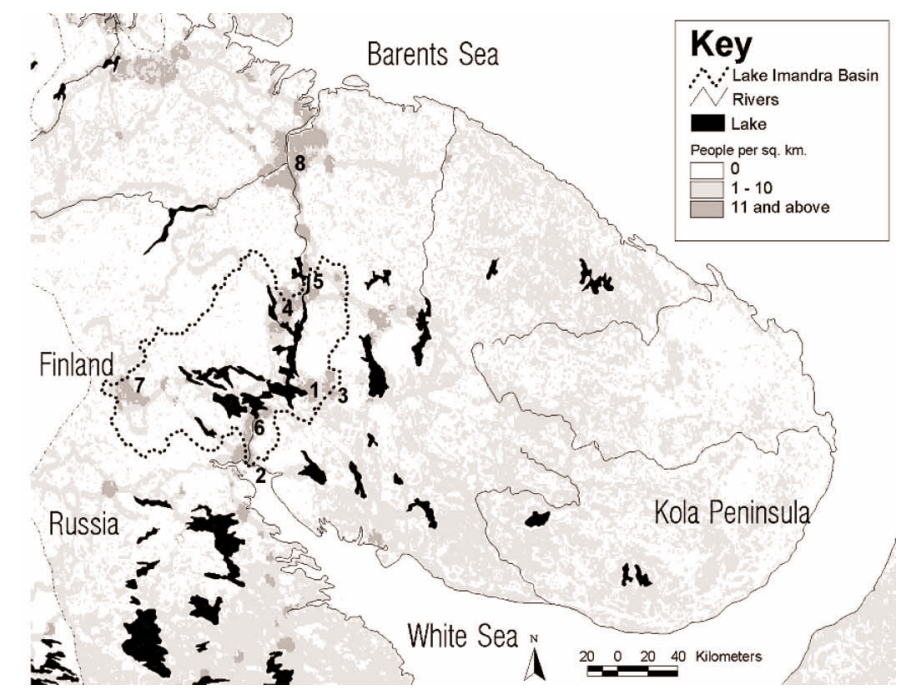

FIG. 1. Location of Lake Imandra watershed in the Kola Peninsula in the North of the European Russia. The map shows large clusters with population density over 10 people per $\mathrm{km}^{2}$, which is quite rare for the Arctic North (LandScan, 2001). Cities are 1) Apatity; 2) Kandalaksha; 3) Kirovsk; 4) Monchegorsk; 5) Olenegorsk; 6) Polyarnye Zori; 7) Kovdor; and 8) Murmansk.

American Association for the Advancement of Science. In close cooperation with local stakeholders, the project is developing multi-scale qualitative and quantitative models and simulations to enhance understanding of Arctic ecosystems, pollutant behavior in those ecosystems, and the relationship between local humans and the environment. These activities are improving knowledge of human-dominated Arctic ecosystems while further developing participatory decision-support systems for resource management.

\section{The Past, Present, and Future of the Kola North}

Human impact on the environment of the Kola Peninsula as a whole began at the end of the last glaciation period (the Valdai), between 8000 and 12000 years ago. According to Myagkov (1976), Saami hunters and gatherers began appearing in the region about 9000 years ago, naming the lake Imandra, whose Saami toponym means 'a lake with a strongly indented coastline' (Rzevsky, 1997).

The Middle Ages marked the beginning of exploration in the Kola by Russians, Danes, Swedes, and others. Between the 11th and 13th centuries, the territory came under the control of Moscow, and in the 15th and 16th centuries, Russian fishing settlements began to appear along the coasts of the White and Barents seas. By the beginning of the 17th century, 196 fishery huts accommodated approximately 1200 fisherman along the coasts (Ushakov, 1984), and over time the term "Pomor" was applied to this coastal group of Russians in the vicinity of Kandalaksha Bay (Bernshtam, 1984). Pomors and Saami set up separate semi-nomadic herding and fishing settlements and established a local barter economy (Lukyachenko, 1994).

In the 18th century, Russian fishing and hunting became more intense. Economic interest in the region was enhanced through exploration initiated by M.V. 
Lomonosov, who produced maps detailing its rich natural resources. With the establishment of the ArchangelskMurmansk Steamer Company in the late 1890s, increased commercial access to the region by Russian hunters and trappers affected its fish stocks, wild reindeer herds, beavers, and river pearls. Krasovskaya (2002) estimates that the approximate population of the Lake Imandra area at the end of the 19th century was about 750 people, roughly 400 Russians and 350 Saami.

When World War I brought blockades of Russia's southern and western ports, an ice-free northern port in Kola Bay on the Barents Sea became a national goal. A large town and port, originally named Romanov-on-Murman, was built in the Kola Bay and connected by railway to the central regions of Russia. Railway construction in 1916 involved some 30000 peasants and 40000 prisoners of war (Luzin et al., 1994), about 4000 of whom were temporarily located in the Lake Imandra region (Krasovskaya, 2002) in short-term, high-impact settlements.

After the 1917 Bolshevik Revolution, Romanov-onMurman was renamed Murmansk, and rapid development of the rich mineral resources of the region began. In 1920, A. Fersman, a Russian geologist, announced that he had located 110 minerals on the Kola Peninsula. These included nickel and iron, as well as one of the world's richest deposits of apatite, a source of phosphorus with a variety of agricultural and industrial applications (Armstrong, 1965). During the Stalinist era (1930s-1950s), the Soviet government began forced migration of political prisoners to the region to exploit these minerals. Large-scale extraction and processing of apatite began around present-day Kirovsk and Apatity. Nickel was mined near what is now Monchegorsk and near the city of Nikel at the Finnish-Soviet border, and iron ore, near Olenogorsk. Large, permanent settlements dominated by massive processing and smelting facilities quickly became the norm in the industrializing region.

From 1932 to 1945, a series of Soviet government decrees provided wage incentives to attract people to the European north, initiating a second migration of civilian industry workers to the Kola Peninsula between about 1955 and the late 1980s. These migration periods brought successive developments: roads, cities, energy grids (including a hydroelectric plant, a nuclear power plant, and coal-burning power plants), large industrial complexes, and all manner of supporting infrastructure.

With the strategic importance of the ice-free Murmansk port and with its mineral riches, the population of the Kola Peninsula went from under 5000 to over 1 million people in less than 80 years. Today approximately 300000 people reside on the Lake Imandra watershed (Fig. 2) in industrial cities largely centered on smelting and mining. The Russian migrant populations have effectively absorbed the Saami and Pomor populations, and today only about 1900 people identify themselves as Saami on the Kola Peninsula, with only some 200 located on the Imandra watershed.

The human impact of industrialized society on ecosystems in the region has been massive. On vast territories one

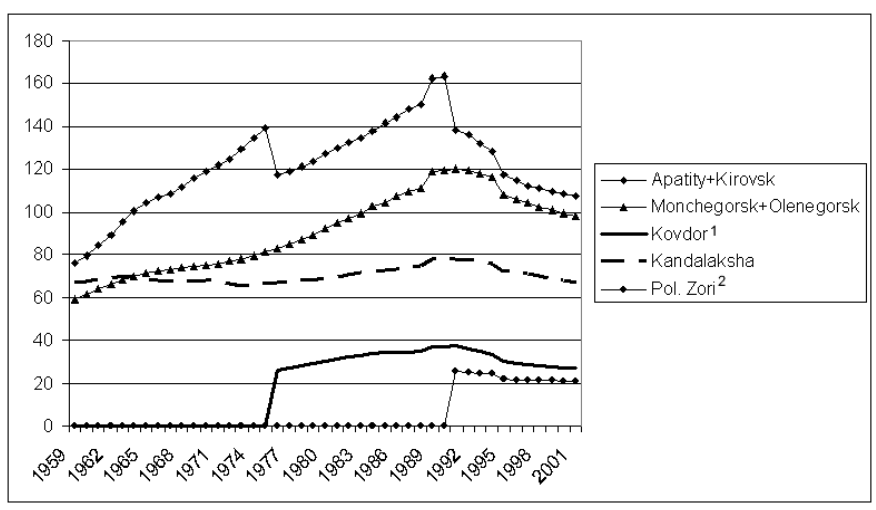

FIG. 2. Population dynamics in the Imandra watershed (in thousands), showing values for each city in the study area. After 60 years of rapid growth, the population has declined steadily since 1990. 1) Demographic reporting for Kovdor was separated from Kirovsk in 1976. 2) Demographic reporting for Polyarnye Zori was separated from Apatity/Kirovsk in 1991.

finds chemical, toxic, and nutrient contamination by human and industrial wastes, deforestation caused by acidification, and other degradation from human activity (NEFCO, 1995). Industrialization of the area has created huge tailing ponds, landfills, increased risks of nuclear and chemical accidents, and high loads of contaminants harmful to humans and many other organisms.

Since the 1980s, the region has undergone yet another transformation as a result of the transition to a market economy. The ecosystems of the Kola are experiencing a recovery attributed to the decreased economic activity. Most important, however, are the complex changes in the social dynamics triggered by the modifications in the economic mechanisms. It is not clear at this time how long the economic stagnation will last; how local populations will bear the economic hardships enhanced by the harsh northern conditions; how vulnerable and adaptable the socioeconomic systems are; what the specific effects on the local ecosystems are; or what the primary development scenarios (sustainable and otherwise) are in this region.

In all these cases, we are dealing with complex, nonlinear systems with multiple feedbacks and fuzzy causality spanning several disciplines, and we have no clearly established methodology to tackle these problems. In our pilot project, we apply and further develop the Participatory Integrated Assessment (PIA) approach (Blumenthal and Jannink, 2000; Mendoza and Prabhu, 2000; Goma et al., 2001; Webler et al., 2001; Lopez-Ridaura et al., 2002) to build a concerted, transdisciplinary effort in systems thinking that provides an umbrella for bringing scientists and stakeholders together and integrating environmental and socioeconomic information and activities.

\section{THE PARTICIPATORY INTEGRATED ASSESSMENT APPROACH}

Understanding how exactly to achieve harmony between economies, societies, and the carrying capacity of 
the environment requires extensive, customized, interdisciplinary knowledge accessible to scientists, policy makers, and the public. Such knowledge creation is difficult under any circumstances. It is even more difficult in the particular environs of the Arctic and the post-Soviet Lake Imandra region, where resources are scarce and public access to the policy-making process is still minimal.

The PIA approach is an application of Post-Normal Science (Funtowicz and Ravetz, 1993, 1994), which dictates that in problems characteristic of highly complex systems, when facts are uncertain, values in dispute, decision stakes high and decisions urgent, there is no one correct, value-neutral solution. Under such circumstances, standard Western scientific activities are inadequate and must be reinforced with local knowledge and iterative participatory interactions. The importance of participatory studies has been recognized for some time (Wadsworth, 1998) and developed under the umbrella of Participatory Action Research (PAR) approach. While the two have much in common, the PIA approach differs somewhat from PAR in two regards. PAR is a bottom-up investigation driven by community and stakeholders, which is usually initiated by social activists to solve particular local problems (Kemmis and McTaggart, 1998). As far as we know, no such activities have yet been launched in the Lake Imandra basin. Our approach is still quite top-tobottom and is driven by scientific studies, which we hope will eventually instigate more community-driven studies and solutions. The other important difference is the level of integration that we try to achieve. We are considering multiple scales and a hierarchy of problems, which requires transdisciplinary studies across many data sets and models. A similar approach is assumed in the field of integrated assessment (Van Asselt et al., 2001). In our case we try to stress the participatory component of integrated assessment.

In applying the PIA approach to the Lake Imandra basin, we have conceptualized an information infrastructure and connected it to the local government, educational system, and civil sector. Problems experienced in this endeavor include addressing issues of scale, prioritizing and acquiring information from multiple disciplines, integrating that information into a cohesive and applicable framework, and invigorating local society to take part in the participatory aspects of these activities.

\section{Watershed Analytical Unit}

Watershed boundaries serve as useful analytical alternatives to administrative and socio-geographic boundaries to overcome problems of scaling. The boundaries associated with a watershed approach are objective. Instead of being the result of some historical, subjective, often unfair, voluntary or contradictory processes, they are based entirely on geographical characteristics such as relief. These are difficult to change, and it makes little sense to dispute them. In this sense, a watershed is a perfect geographic unit around which to build consensus among the multitude of administrative, legal, and public bodies located within it. The flow of water serves as an indicator of the relief and landscape characteristics, on the one hand, and as an integrator of many of the processes occurring within the watershed, on the other. A watershed in this case is simply a way to clip a part of the regional system (the Kola North) that can be representative of the processes occurring in the larger regional system, yet small enough to analyze fairly rapidly.

Watersheds and sub-watersheds provide a hierarchical context, which is important for a management scheme and instrumental for upgrading and downgrading, zooming in and out, or changing resolution, depending upon the type and scale of the managerial problems to be resolved. This hierarchical approach adds flexibility to the management scheme, breaking the usually rigid connection between policy and spatial and temporal scales. In most cases, the policy problem drives the scale, and it is usually unclear who should formulate the policy question and over what scale. With the hierarchy provided by the watershed approach, however, the scale of the targeted management object becomes less crucial, as long as it is presented as an element of the whole hierarchical structure.

On the other hand, this nontraditional area delineation implies some obvious hurdles. Most of the socioeconomic data sets are collected for administrative units and must be processed to match the watershed areas. In the case of Imandra, fortunately, most of the development is localized and can easily be placed within the boundaries of particular watersheds. Data that exist only for the whole Murmansk oblast are a significant problem: in such cases, we usually scaled the numbers in proportion to the population densities in particular Imandra watershed locations.

\section{Multidisciplinary Data and Modeling}

These data and information are largely integrated through a series of modeling exercises. The PIA assumes a broad definition of a model, and it employs models in any problem that might benefit from them, using them as analytical, conceptual, and visualization tools for scientists, policy makers, and local people (Van den Belt, 2004). These models therefore differ according to their intended audience. They include:

- Data models based on measurements and experiments (graphics, charts, diagrams);

- Qualitative, conceptual frameworks of systems and processes involved (flow-charts, interaction matrices, etc.);

- Quantitative numeric models used to formalize the qualitative models (empirical and process-based formalizations);

- Mathematical methods and models used to analyze the numeric models and interpret the results (numerical methods, analytical solutions); 
- Decision-making models that transform values and knowledge into actions (simulation systems, graphic user interfaces).

Simulation aspects of these models can be nested together and linked to remote-sensing imagery and other types of visualizations, ideally making them directly applicable to local resource management needs. The ultimate level of complexity of the simulation modeling process is yet to be decided. Our original plan was to develop a dynamic, spatially explicit, integrated, ecological economic model like the ones built for two Maryland watersheds, the Patuxent and its sub-watersheds (Costanza et al., 2002; Voinov et al., 1999a, b) and Hunting Creek (Seppelt and Voinov, 2002). Most of the processes and modules currently available in the models built for the Maryland watersheds are applicable to the Arctic regions, except that the parameters need to be adjusted to represent the specifics of those environments. This approach offers a unique opportunity to link the temporal and spatial data available from various monitoring efforts to increase understanding of how ecosystem functions interact with socioeconomic dynamics. We have assembled most of the spatial data sets that are needed for this approach; however, it is not clear to what extent the stakeholders and decision makers are ready to take full advantage of simulation tools at this level of complexity.

Clearly, sophisticated simulation models require extensive data, much preliminary work, and well-trained personnel to maintain and use them. They make sense only if there is sufficient local need and support to sustain the effort. At this time there is no evidence that this will be the case in the Imandra watershed. However, the PIA approach is configured in such a way that products can be derived at earlier stages, before the whole data set needed to produce the ultimate full-scale spatial simulations is available. With the modular approach, simplified models of subsystems and processes are assembled to increase understanding and to flesh out the most crucial elements of a complex landscape. These simplified models, some of which are presented on a project web site at http:// giee.uvm.edu/AV/KolaModels, also provide intermediate tools for decision support even with incomplete or fuzzy data sets. They can help users to better understand the flow of material and information in the system, identify the possible feedbacks and causal links, and prioritize data collection and scenario development (Voinov and Costanza, 1999). This modeling approach also serves as a tool for integrating available data by indicating gaps in the information that must be filled.

\section{Participatory Integration}

Integrating scientific activities with local policy makers, commercial interests, educators, and the citizenry (referred to as "stakeholders" in this project) is critical to the research. The decision-making community must extend beyond the scientists and "experts" to include representatives of the stakeholders affected by or affecting the problem. This is necessary both to include the different values of the different actors and to incorporate different forms of expertise derived from intimate contact with a specific system and observations not limited by disciplinary blinders (Martello, 2001). Decision makers drawn from a broader pool are more likely to think creatively and come up with innovative solutions. This approach seems particularly effective and necessary in the Russian Arctic, where formal political participation is low but independent thinking and personal ambition have strong traditions.

The modeling activities in particular require wide stakeholder participation, starting with a series of workshops whereby local people define the goals of the studies, learn about the system structure, review available data sources, and prioritize the monitoring programs. Involving the stakeholders in the modeling process increases their awareness, and they contribute to consensus building on economic development, resource management, and strategic planning issues. The goal is to integrate these models within a transparent and interactive framework and couple them with stakeholders at every stage of the process. In addition, the project seeks to integrate stakeholders' individual models into the overall structure and, in turn, to help organize the local stakeholders to communicate understanding, values, and concerns. Stakeholder input is especially important in developing models of economic diversity that would help sustain the watershed and the human populations living in it (MüllerWille and Hukinnen, 1999).

To meet these needs, a dynamic and energetic interface was created between the scientific information and local government and industry leaders, educators, and citizenry. This interface allowed the gathering of critical socioeconomic information on local people and institutions, appraisal and verification of scientific hypotheses under development, and formulation of realistic future scenarios. A series of stakeholder workshops and surveys initiated implementation of this participatory interface. Most important is not the specific model implementation that is developed, but rather the ongoing process of integrated assessment by local and regional stakeholders at all levels, using models of varying sophistication to fully understand and manage their complex resources (Costanza and Ruth, 1998).

Scientists and stakeholders outside the Lake Imandra area also have access to the project. All the data and findings are archived at two mirror web sites: one at the American Association for the Advancement of Science (AAAS), (http:// www.aaas.org/international/eca/kola/), the other at the Kola Science Center (http://imandra.ksc.ru/index-r.html). The web connections are also essential for the international team to communicate and to keep all the participants up to date on progress. Local stakeholder web access, although improving, is still limited. In addition to the Kola Science Center, governmental agencies have quite reliable web access, and private companies offer dial-up services for those who can 
afford it. An increasing number of schools have web access; one such node, for a school in Polyarnye Zori, has been sponsored by this project.

\section{RESULTS}

The PIA approach has brought a large amount of information to bear on sustainable resource management in the Lake Imandra basin, while further developing the necessary science and policy infrastructure. Some of this information has been organized into preliminary theme tracks on key dynamics, including historical, environmental, demographic, ecological, and economic dynamics, and those of local stakeholder perceptions. All these dynamics form the basis for the continuing studies; combined with models, they offer understanding on likely and alternative development paths impacting the local environment. As part of these efforts, we compiled data for the following types of processes and system elements:

1. Hydrologic cycles of the Lake Imandra basin;

2. Population consumption patterns, including land use, mineral extraction, water use, food production and consumption (by different sectors of the society), and some description of indigenous knowledge of populations living in the region before large-scale development began (demographics, ethnology, sociology);

3. Contaminant transport and water quality information;

4. Biogeochemical cycles (including environmental waste absorption and buffering capacity) for various contaminants and nutrients, such as heavy metals, phosphates, SOx, NOx, etc.;

5. Non-renewable resource stocks (e.g., apatite and other ores), depletion rates, accessibility and market trends;

6. Renewable resource stocks (e.g., timber, fish, berries, mushrooms), depletion rates, growth rates and market trends (including ecotourism potential);

7. Environmental change in the region and expected impacts;

8. Economic assessment of ecosystem services and costs of pollution control;

9. Ecosystem health indicators (fish stocks, water quality, biodiversity, biological productivity, human health, etc.); and

10. Future alternative development scenarios developed by regional stakeholders.

Most of these data sets are available to registered users from the project web pages.

Simply starting to compile this information in a participatory fashion has proven to be a useful integrating tool. The strong scientific enterprise of the Soviet era still exists in Russia, albeit in reduced form, and combining this body of knowledge with more familiar Western libraries and archives has required building an extensive network of relationships. The historical data are collected from records kept at various governmental agencies and research institutions in the region and elsewhere (e.g., Moscow and St. Petersburg), from open-source remote-sensing and other mapping resources, and from literature (e.g., INEP, 1999).

Remote-sensing and other geospatial data provide an accurate and visually compelling backdrop in which to embed related data and models. Landsat 7 images quantify key variables needed by the models, including vegetation extents and industrial impacts. The expansive mining activities around Lake Imandra are easily visible in Landsat imagery, as are the nuclear power plant, smelters, cities, and supporting infrastructure. Also detectable are areas of highly degraded vegetation. Figure 3 a shows damaged vegetation around Monchegorsk detected through its abnormal infrared signature, and Figure $3 \mathrm{~b}$ shows the correlation with data obtained from ground samples. Field work is underway to refine methods for rapidly assessing degraded vegetation from satellite imagery. Such imagery is essential for demonstrations at workshops and helps understand the extent and trends of ecological damage.

\section{Key Environmental Dynamics}

Lake Imandra is one of the few aquatic systems in Russia (and probably the only one in the Russian Arctic) for which we have long-term observations for all major trophic levels to compare with the economic development indices. Three major recent periods of ecosystem change have occurred in the lake: in 1940-70, human load was increasing, and pollution exceeded what normal ecosystem functions could absorb; in 1970-90, the lake had maximum pollution, and degradation peaked; and in 19902000, a decrease in human load during economic collapse was accompanied by a trend towards improved water quality and healthier biological communities.

The Lake was originally an oligotrophic water body with hydrocarbonate-calcium ionic content, very low turbidity, and low concentrations of microelements. The period of industrialization changed the hydrochemical state, bringing higher concentrations of sulphates, higher mineralization and turbidity, and pollution by heavy metals. Municipal waste and emissions from the apatite industry brought loads of phosphorus, the limiting nutrient, into the lake, and as a result there are clear indications of eutrophication. A decline in species diversity is primarily due to losses of those Arctic species most vulnerable to pollution. The toxic effects of heavy metals and changes in the physical and chemical state of the environment resulted in corresponding changes in fish pathology and species structure (Moiseenko et al., 1995).

During the 1990-2000 period of decreasing human impacts, water quality has improved, showing a trend to restoration of certain communities. However many indicators are still very different from those in pristine Arctic lake ecosystems, and the eutrophication trend is now more dominant an issue than toxic contamination. Lastly, new algae communities with less species diversity, established 


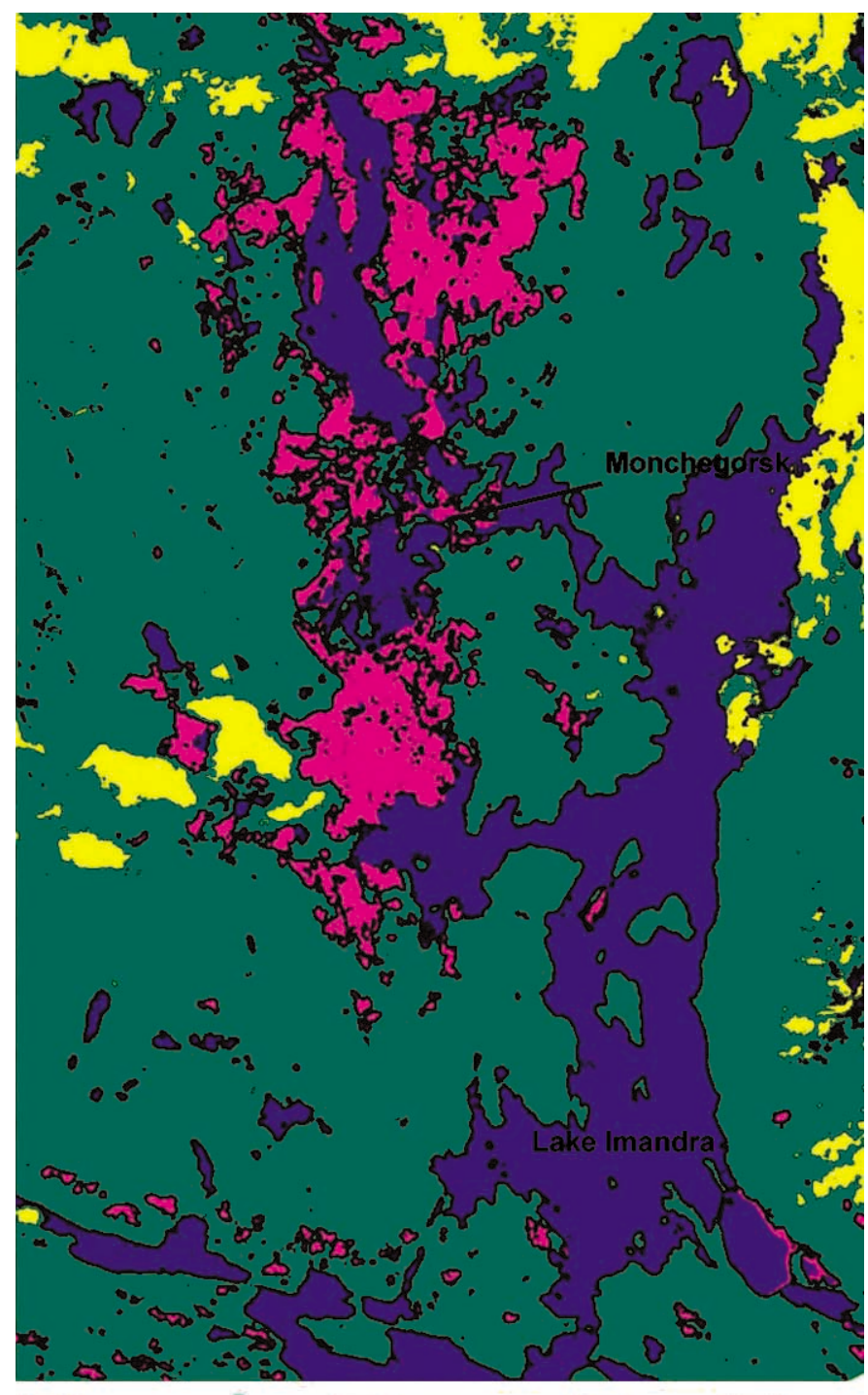

degraded vegetation

other land area

clouds

water

FIG. 3. a) above: Classified subset of Landsat imagery from July 2000, showing damaged vegetation in low-lying areas (red) around Monchegorsk, easily distinguished from surrounding vegetated areas by a simple analysis of the infrared signature. b) right: Land-use and land-cover map based on data from ground samples correlates with degraded vegetation in Landsat image.

during the periods of degradation, are now growing in numbers and biomass (Moiseenko, 2002).

\section{Key Socioeconomic Dynamics}

Socioeconomic data provide the bounds of likely and possible future human impacts on the local environment. Analysis of the Imandra watershed reveals several local problems related to the aging and increasingly marginalized local population. This does not bode well for the local environment given the ongoing, high-impact industrial activities of the region.

Average life expectancy for the Murmansk region of the Kola Peninsula in 1995 was 63.8 years. An aging population is now a typical trend for the Russian North. In the Lake Imandra area, the number of retired people was 167.7 per

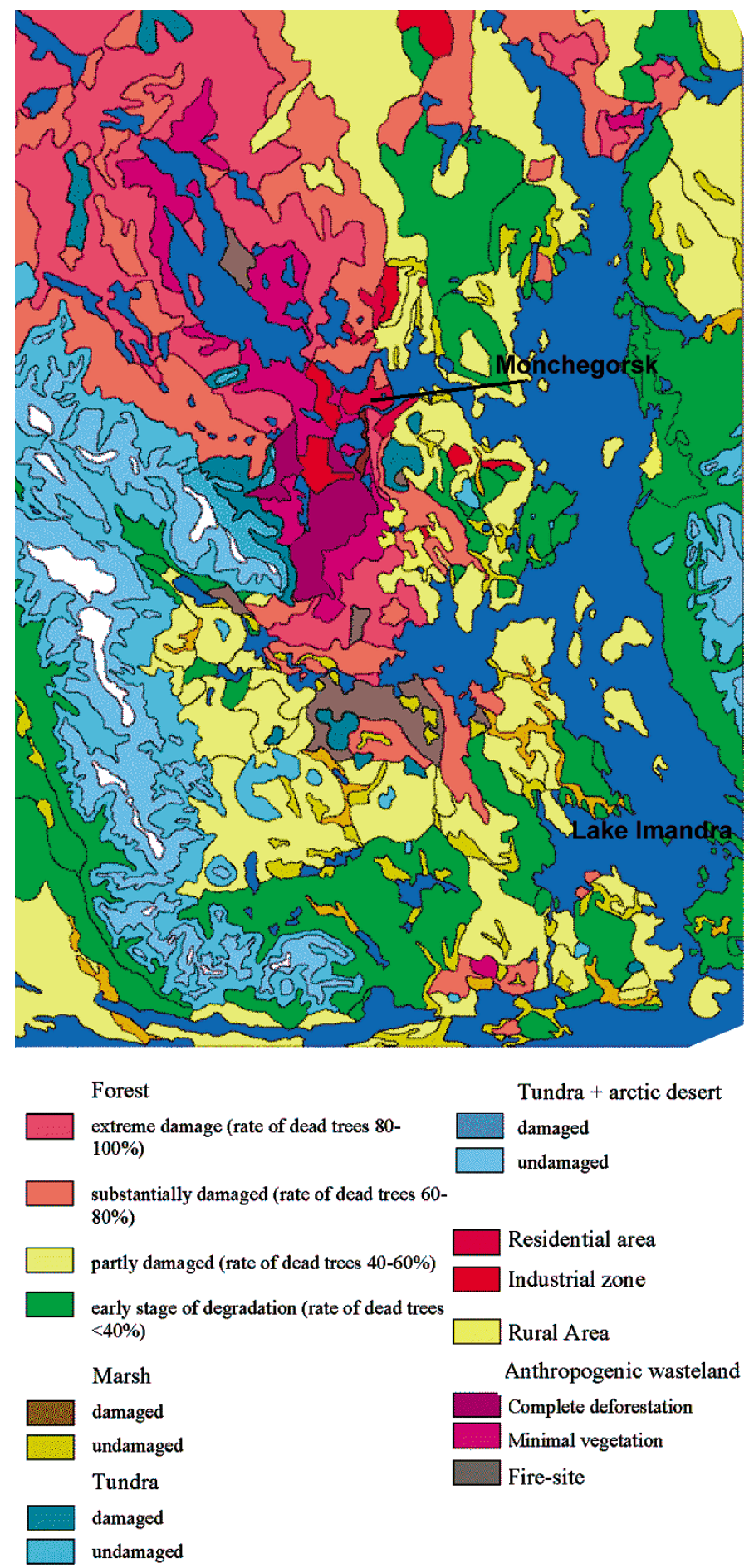

thousand at the beginning of 1992 and 208.5 per thousand in 1996. At the same time, the financial resources allotted for social security have significantly diminished: in 1996, they were at $64 \%$ of their 1990 levels. Comparison of the aggregated consumer price index with pension payments between 1992 and 1996 indicates that the real purchasing power of pensioners fell 2.3 times (Luzin et al., 1998). If in 1995 the average pension in Russia was $48.3 \%$ of the average salary, in the Murmansk Region it was only 33.9\%.

In social security terms the region has never been self sufficient, and it is even less so now. The collapse of many 
social security programs has dramatically decreased the ability of pensioners to leave the area, further burdening the local social safety net. Further, immigration to the area has sharply decreased, and $70 \%$ of migrants leaving the area are of working age. These migrants, together with children under 16 , constitute $90 \%$ of the total, and $60 \%$ of the total migrants are between the ages of 16 and 29. In the Murmansk Region during 1993-95, the number of employees decreased by 48.9 thousand, or by $9.4 \%$ (Luzin et al., 1998). This obviously indicates that the cream of the local labor force has left the area, and the pensioners who remain behind will face increasing uncertainty regarding the social safety net as well as resource management.

Ideas about this out-migration conflict: on one hand, evacuation of people, especially pensioners, decreases the burden on local resources and simplifies maintenance of the municipal infrastructure. The World Bank seems to be in favor of this approach and is promoting emigration from the Russian North by its recent loan for the Norilsk region (Pravda, 2001). On the other hand, there is a feeling that stripping the population of its elderly ruins the linkage between generations, creating lacunas in historical and social connectivity in the society. This presents a policy dilemma for the area, and as discussion continues about what to do, the population for the most part has been voting with its feet.

\section{Integrated Dynamics}

Correlating data from the various sciences makes it possible to decipher complex economic and ecologic interactions. The data show that as part of the recent economic collapse in Russia, mineral extraction activities have decreased substantially, as have the major point sources of pollution in the Lake Imandra watershed. Over 160000 people have left the Kola Peninsula, leaving a population of approximately one million inhabitants. Figure 4A shows coupled dynamics of apatite extraction and population in the Apatity-Kirovsk municipal area. Not surprisingly, they are very well correlated. During and after the 1920s, the population was steadily growing, as was the production of apatite. In the early 1990s, however, the breakup of the Soviet Union brought a dramatic change. Production fell sharply, and so did the population. However, a closer look at how the major factors of population dynamics changed (Fig. 4B) indicates that, in fact, net migration into the region and birth rate had started to decline even before the sudden fall in economic output, whereas mortality increased at about the same time as the economic fall. Interestingly, the total population continued to decrease after 1995, despite the return of some economic activity. Again in this case the net migration seems to have been a precursor of economic development: it changed its trend a few years earlier than the economic indicator.

Moiseenko (2000) observes that the economic slowdown led to much improved water quality and watershed recovery that is faster than assumed in the Arctic. Some recent field studies confirm these estimates. For example, the distribution of nickel concentrations in the surface waters

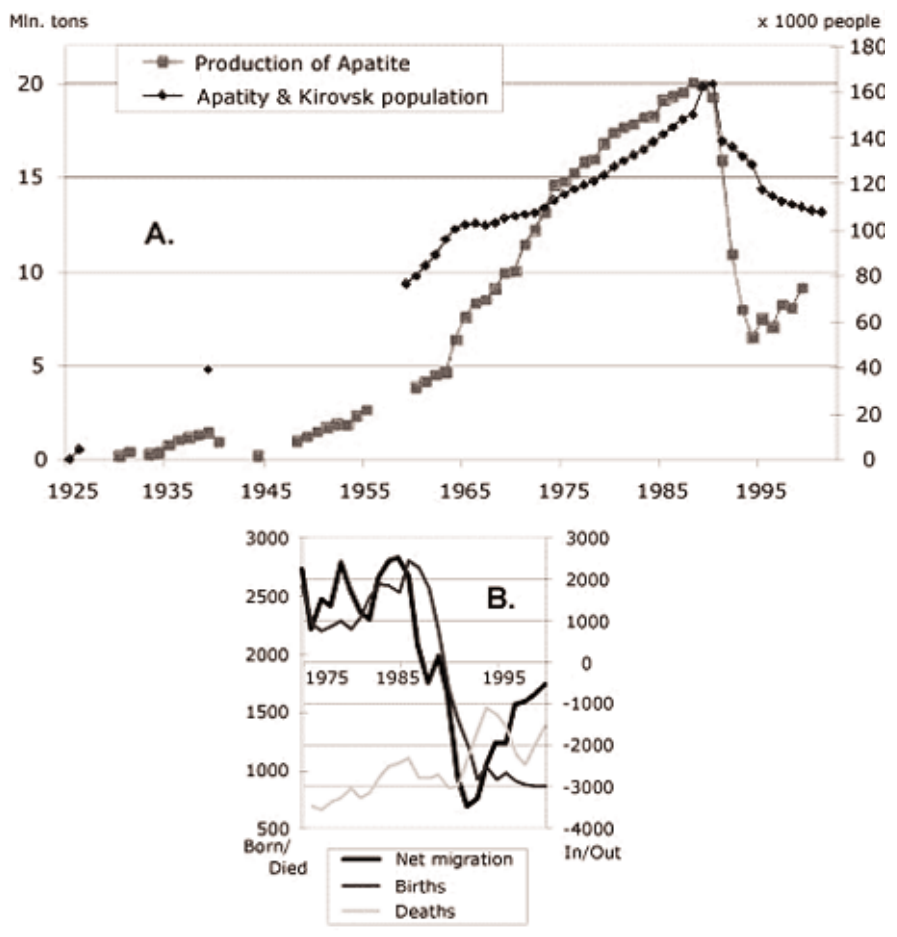

FIG. 4. Population dynamics and production of apatite in the Apatity-Kirovsk municipal region during the last 70 years. Both population and production grew steadily until the economic meltdown in Russia in the early 1990s. The drop in economic growth resulted in sharp emigration from the area. Interestingly the slow economic growth of the last few years somewhat reversed the migration trend; however, the total population continued to decline because of increased mortality rates and lower birth rates.

of Lake Imandra, averaged over nine lake zones as defined by Moiseenko and Yakovlev (1990), is compared for 1992 and 2001 in Figure 5. Nickel is the major pollutant discharged by the Severonikel enterprise in Monchegorsk, and this is clearly seen in the distribution patterns. After 1992, there was a sharp decline in industrial production of all major enterprises in the watershed, and the amount of nickel entering the lake ecosystem dropped. Moreover, the 2001 monitoring showed visible declines in the concentration of all major pollutants: copper was half its previous level, sulfates and nitrogen were reduced to $74 \%$ and $59 \%$, respectively. During the same time, however, phosphorus concentrations increased. Further research will determine how this decline in pollutants is propagating throughout the lake's trophic levels, though it is already clear that the economic meltdown was beneficial to the ecological components of the system. At the same time the socioeconomic effect was quite adverse, with no direct tangible benefits apparent from the ecological recovery. Less heavy metal in the lake and cleaner air have certainly provided some health benefits to local residents; however, the connection may not be as obvious as the more direct impacts of the economic slowdown.

So far, human health has shown no evidence of any improvement from the reduced pollutant loads. Medical statistics since 1990 show a clear growth trend in the number of illnesses of the genitourinary system (glomerular 

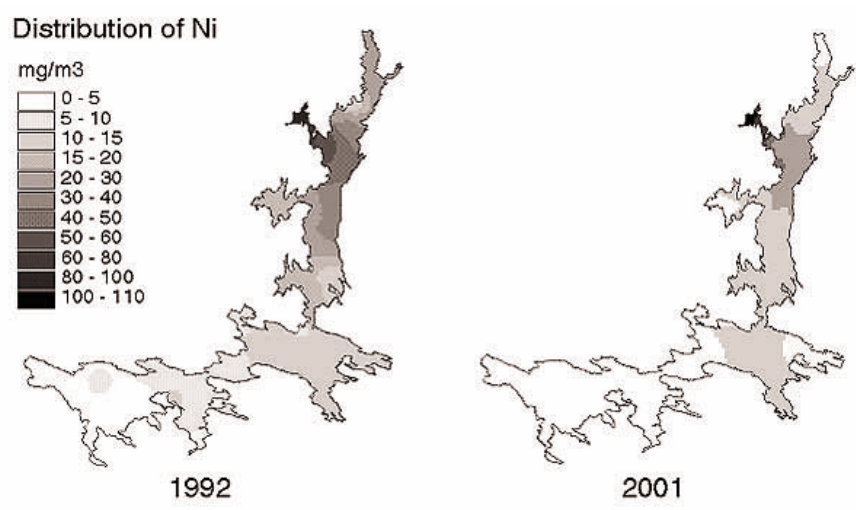

FIG. 5. Comparison of nickel concentrations in Lake Imandra in 1992 and 2001 based on annual monitoring of water quality in the surface and bottom layers from 28 sampling stations on the lake.

disorders, urolithiasis, salpingitis, oophoritis, etc.). The total general case rate (calculated as number of cases previously diagnosed + number newly diagnosed $\times 1000 \div$ total population of the region) increased steadily from 1991 to 2000, from 77.9 to 105.2 in Apatity and from 52 to 66.9 in Kirovsk.

Table 1 shows a steady increase in the rate of occurrence of almost all classes of illness for which we found data. An overall increase in mortality is consistent with an increase in life-threatening illnesses, and health data indicate a significant increase in overall mortality from certain diseases and disorders (Table 2). Infant sickness is even more troubling; most indicators are $35 \%$ to $38 \%$ higher than the averages for Russia. Interestingly, the only improvement observed is a decrease in the number of alcohol-related deaths. This decrease is attributed to the new market economy and higher unemployment; however, the perceived improvement may be an artifact of skewed statistics and hidden domestic alcoholism.

Some of these health problems may be linked to the quality of the drinking water obtained from the Lake. Apparently less contaminated wastewater discharges do not yet translate into improved quality of drinking water. However the aging population may also explain the rise in health problems: the younger ones are the first to leave, while the more vulnerable elder and retired people lack opportunities to relocate and tend to stay. The collapse of the state-subsidized free medical care has clearly had devastating impacts on human health, and improved environmental quality cannot compensate for the loss of medical care in the short term.

\section{Stakeholder Dynamics}

Compiling and communicating information to local people has created the beginnings of a dynamic and energetic interface between science, policy, and the community. This interface has allowed the gathering of critical socioeconomic information on local people and institutions, appraisal and verification of scientific hypotheses under development, and formulation of realistic future scenarios. A series of stakeholder workshops and surveys initiated this data gathering. The initial reconnaissance workshop brought together over 45 local scientists, policymakers, and citizens, including major participants from the Kola Nuclear Power Plant, the regional ministry of natural resources, and the mass media. The workshop included visits to three facilities that are major point sources of pollution of Lake Imandra-the Severonikel processing plant, the Kola Nuclear Power Plant, and the Apatite processing plant in Apatity-which established direct linkages between scientists, other project members, and influential members of industry. This workshop explained, refined, and established the initial common science and policy goals and teams for the project.

During a second workshop series, the project team traveled to four major cities in the basin, Apatity, Monchegorsk, Polyarnye Zori, and Kandalaksha, to present the project approach to the general public. Members of the audience were invited to speak at any time about their perceptions of needs and problems and how such a study might help them. The meetings took on the atmosphere of a "town meeting," which was new to many people more accustomed to Soviet-style central planning. Local press representatives were also present and interviewed speakers and participants after the workshops.

The most common theme presented by stakeholders in these workshops was that the federal and regional governments monopolize political power and allow little input or concern about local problems: a classic example of marginalization. ("There is no feedback between decision

TABLE 1. Annual incidence of illnesses (by class) in the total population of the Lake Imandra watershed from 1995 to 1999.

\begin{tabular}{|c|c|c|c|c|c|c|}
\hline Classes of illnesses & 1995 & 1996 & 1997 & 1998 & 1999 & $\%$ change $1995-99$ \\
\hline Respiratory system & 234.6 & 203.1 & 247.8 & 206.9 & 248.6 & +6.0 \\
\hline Circulatory system & 121.4 & 130.9 & 134.9 & 139.2 & 167.6 & +38.1 \\
\hline Genitourinary system & 69.9 & 87.9 & 91.8 & 94.6 & 99.7 & +42.6 \\
\hline Musculoskeletal & 86.2 & 98.3 & 100.1 & 107.3 & 108.2 & +25.5 \\
\hline Digestive system & 77.2 & 84.6 & 89.1 & 86.2 & 84.1 & +8.9 \\
\hline Nervous system $^{1}$ & 138.9 & 140.1 & 152.7 & 153.1 & 37.8 & $+10.2(1995-98)$ \\
\hline Cancers & 29.9 & 35.7 & 38.2 & 40.1 & 39.2 & +31.1 \\
\hline
\end{tabular}

${ }^{1}$ Since 1999, the neuro-ophthalmologic and ophthalmologic illnesses have been considered separately from the total illnesses of the nervous system. 
TABLE 2. Dynamics of mortality (per 100,000) in cities $^{1}$ in the Lake Imandra watershed.

\begin{tabular}{lcrc}
\hline \hline Causes & 1991 or $1992^{2}$ & 1998 & \% Increase \\
\hline Circulatory disorder & 338.2 & 472.9 & 39.8 \\
Cancers & 127.1 & 150.3 & 18.3 \\
Including liver cancer & 6.1 & 9.8 & 60.7 \\
Accidents, poisonings & 119.1 & 133.8 & 12.3 \\
Including alcohol poisoning & 16.2 & 6.3 & -61.1 \\
Including suicides & 23.6 & 31.2 & 32.2 \\
Tuberculosis & 1.4 & 4.5 & $221.0(1995-98)$ \\
Respiratory disorder & 17.6 & 20.9 & 18.8 \\
Digestive disorder & 21.8 & 23.7 & 8.7 \\
\hline \hline
\end{tabular}

${ }^{1}$ Cities included in the survey were Apatity, Kandalaksha, Kirovsk, Monchegorsk, Olenegorsk, Polyarnye Zori, and Kovdor.

${ }^{2}$ Data records were not entirely consistent. For some indicators, we had 1991 data; for others, 1992 data.

makers and us, the people. They don't share information!" Apatity. "The enterprise is a monopoly. They own us. We can't beat them."- Monchegorsk.) Likewise, people felt that rich enterprise owners also did not care about local environmental and health conditions, since they exported themselves and their money from the region to Moscow and abroad. ("In 10 years we shall either die off or move out of here." Apatity. "The owners don't live here. They don't care." Monchegorsk.) The predictable result of this marginalization is overall inefficient resource management and increased burdens on local people and infrastructure. ("All ecological taxes and fines are siphoned out of the region. They never come back." - Apatity. "Economic loss is ecological gain. The more enterprises close, the better for the environment." - Apatity. "We can't solve our ecological problems unless we solve the economic ones." - Kandalaksha.) There are simply too few reliable mechanisms for communication between the local people, scientists, and decision makers, yielding ineffective environmental and social policy ("Scientists are also people!" - Apatity). Civil sector organizations are nonexistent or very weak, and while public meetings and newspaper articles may provide some venues for expressing local concerns, there is as yet little experience in policy activism. ("Women should be more socially active. Men will follow." - Kandalaksha.) Despite their marginalization, local people remain very industrious, and overall optimism and a desire to improve their lot were also widespread. ("We can survive. We need to develop tourism, sports industry, deer herding, aquaculture, and universities. There are lots of things we can do!" - Polyarnye Zori.) Increasing the amount of local science-based political activity has emerged as a crucial requirement of the PIA approach.

To complement these workshops, we administered an informal survey to delineate trends on the ecological, sociological, economic, and demographic attitudes in the four cities of Apatity, Monchegorsk, Polyarnye Zori, and Kandalaksha. Most of the survey questions were multiplechoice, and some were open-ended. The Institute for Economic Problems at the Kola Science Center issued more than 400 of these informal surveys during and after the workshops. Though this method does not ensure a sampling representative of the population as a whole, it is useful to pre-test some of the questions that will be used in later phases of the project. The use of an informal survey also established a localized questionnaire methodology, which allayed the Soviet-era fears of the local scientists and population. Even with this methodology, response rates were fairly low. Surprisingly, Monchegorsk, the city with the least participation in the workshop, had the highest response rate, returning $40.2 \%$ of the total questionnaires issued in that city. The distribution of responses among other cities was: Apatity, 19.7\%; Kandalaksha, 18.4\%; Polyarnye Zori, $8.7 \%$; Kirovsk, 5.5\%; and other places, $7.5 \%$. Of these respondents, $29.7 \%$ were men and $70.3 \%$ were women.

Respondents were asked to evaluate their life on a scale of 1 to 5, with " 1 " standing for "totally unsuccessful" and " 5 " indicating "happiness." Surprisingly, of 139 respondents, only five people (3.5\%) rated their life as 1 and six $(4.3 \%)$ as 2 , while $39(28 \%)$ chose $3,65(46.9 \%)$ chose 4 , and $24(17.2 \%)$ chose 5 . So in spite of all the hardships of the transitional economics, $64 \%$ are optimistic about their life achievements. Further, $42.4 \%$ of respondents think that they have the ability to improve their life, while $48.1 \%$ chose the more neutral answer "maybe, to a certain extent." This optimism seemed startlingly contradictory to the general feeling that prevailed during the workshops, when most of the speakers complained about their total inability to participate in local governance and dependence upon the federal and regional rulers. While the surveys already indicate that $53.9 \%$ of the respondents expect the population to decrease in the next 10 years, only $15.5 \%$ are planning to leave and $46.9 \%$ are definitely staying. Yet $66.8 \%$ would rather have their children leave the area to live elsewhere, and only $26.7 \%$ would want their children to stay.

Twenty-five percent of respondents spend their recreation time on Lake Imandra, affirming its strong importance and potential in that regard. Interestingly, $40.9 \%$ believe that the lake's water quality has deteriorated during the last 10 years, which is in fact contrary to the scientific evidence. Another $8.5 \%$ said the water quality has improved, and $31.4 \%$ said they do not know. It is very likely that human perceptions of environmental issues are driven by expectations and desires, while the overall level of local knowledge about the environment is low. When people know little or nothing about the ecosystem, they may be less concerned about its state and assume that it is in good shape. The more people learn about an ecosystem, the higher are their concerns and expectations and the lower their evaluation, despite the fact that the ecosystem may actually be improving. The ratio between the "deteriorated" and "improved" evaluations of water quality in the lake differed greatly from city to city: Apatity (2:1); Monchegorsk (7:1); Kandalaksha (10:1); Polyarnye Zori (18:1).

Kandalaksha and Polyarnye Zori are currently the areas that contribute the least to lake pollution (the nuclear 
power station has great potential for environmental damage, but almost zero emissions and discharges at present). The Apatity, Kirovsk, and Monchegorsk areas are the most polluting, with local economies and social infrastructure significantly dependent on the major mining and industrial enterprises in these cities. Thus it is likely that people of these cities cannot afford to be more environmentally concerned because their jobs and salaries are provided by the major industries.

\section{DISCUSSION: FUTURE SCENARIOS}

Scenario development is an important output of the PIA as it draws the information gathered into a common package that actively engages local stakeholders. Given the interplay of historical, environmental, and socioeconomic factors, it is clear that the existing scenarios will be shaped by insurmountable energy issues as well as by stakeholder perceptions. Combining these perceptions with other information, we have outlined distinct development scenarios describing likely future conditions in the Lake Imandra watershed. These scenarios serve as a basis for our own further analysis and are likely of use to other researchers and the policy community and local residents concerned with the area. The primary scenario includes an industrially intense, free-market development path. Alternative scenarios include the introduction of ecotourism or other recreational industries and possibly government support of a high-technology sector.

Developing any labor-intensive economic sector requiring large and permanent settlements may not be a moneymaking proposition in gross terms; however, it has overall socioeconomic benefits and therefore must be actively pursued. If the regional government accepts the social obligation to provide at least a basic level of living to the citizenry in the Kola Peninsula, then it must view this subsistence income as a fixed cost, and existing infrastructure as a sunk cost already incurred, which cannot be recovered but may possibly be capitalized on. As long as these costs of economic activities are less than revenue, production should continue. Overall, subsidizing some form of economic activity in the Kola may be the least expensive social safety net available. Without any economic opportunity, people will need to leave the region, though relocation is economically and psychologically expensive, or suffer serious hardship. Unemployment is high throughout Russia, and even if people relocate from the North, they are unlikely to find jobs elsewhere.

\section{Energy Balances}

Central to all future scenarios in the Kola Peninsula is the available energy balance. Much of the economic infrastructure that has been developed in the Kola was made possible by the low energy prices in Russia. Since the heating season starts in October and lasts till May, and the polar night takes an extra toll for illumination, energy requirements are enormous. Transportation requires clearing the snow from roads and modifying vehicles to function in the winter cold and dark. It is clearly more expensive to live in the North than in more favorable climates.

Something that still remains unclear is how the region will do once the cheap, subsidized energy supply starts shrinking. This can happen relatively soon if Russia becomes a full partner of the World Trade Organization and is forced to raise internal oil prices to the level of global prices. A more immediate problem is that two of the four blocks of the Kola Nuclear Power Plant are due to be closed down because of age. While closing some of the blocks might reduce thermal pollution of water, it will also create an energy shortage. Energy alternatives such as coal, oil, or wood are costly and likely to stress the ecosystem functions even more.

If local industries become less competitive because of higher energy prices, or if costly pollution prevention measures are imposed, these industries are likely to shut down. Even while they are still operating, it is not clear whether maintaining the full social infrastructure they provide (schools, kindergartens, hospitals, pensions) will be feasible. Increased energy prices could quickly turn the steady out-migration from the Lake Imandra watershed and the Kola Peninsula into an exodus.

\section{Stakeholder Perceptions}

The second most important driving force in the Lake Imandra area, closely following the basic issue of energy, is stakeholder attitudes and perceptions. We have collected and analyzed these perceptions to help form the basis for scenarios. Despite the harsh environment and difficult development history, stakeholder perceptions indicate dogged optimism and determination about possible futures in the Lake Imandra area. Most stakeholders in our survey feel that, with some retooling, the Kola Peninsula can prosper economically while maintaining a healthy environment. The first of the prevailing perceptions held by stakeholders is that a future based on a technologydriven model could succeed. If the big enterprises would update their facilities and improve their extraction and waste disposal techniques, then things would get better on economic, environmental, and social fronts. Technological advances would help the region get a larger share of the global market for these minerals and would also include improved transportation and other infrastructures needed to support the existing industries.

Another prevailing perception among the surveyed stakeholders is that a conservation and sustainability approach is a viable option; individuals and institutions would change their consumption patterns to embrace conservation management principles. A third perception is that a regulatory approach could work: fines would be issued, complemented by an enforceable regulatory regime that would keep revenue from fines in the local 
jurisdiction. An alternative version of the regulatory approach is the incentive approach, which would develop tax relief and other rewards for responsible practices. The last two approaches deal primarily with demographics and economic growth. The first is a minimalist approach: the large enterprises would provide the minimum infrastructure needed to extract and process the minerals, and workers would come in and out of the region as needed. The second is a growth approach: national incentives would help to make these enterprises more competitive on the global market and foster economic growth in the region.

\section{Primary Development Scenario}

Concerns about energy availability and the stakeholders' perceptions indicate that further involvement in the global minerals market is likely for the Kola Peninsula. Residents of Lake Imandra can likewise expect further social and economic shocks through participation in the world trade system. Few alternatives exist, and the collapse of the local mineral-processing industries has already reduced opportunities for Kola residents to participate in the global cash economy. Further, the integration of the economy into the world market has entirely changed the demand patterns for the major products produced in the region. Under a planned economy, most of the production was secured for domestic consumption. Now, the regional economy has become much more dependent on the world market. The stagnation of the Russian domestic market in the process of economic decentralization caused sharp increases of exports of nickel, aluminum, and other metals. As the mineral wealth of the former Soviet Union flooded the world market in 1991 92 , world prices for nickel declined by $13 \%$, and those for aluminum by $28 \%$. Another fall of nickel prices in $1997-$ 98 sharply deteriorated the situation at the Pechenganikel and Severonikel enterprises and aggravated the social situation in the cities around these enterprises (Luzin et al., 1999). All this, in its turn, deteriorated regional export efficiency, which was the only source of hard currency. Integration of the Kola North into the free-market system will continue to be a painful process, and it is not yet clear, given energy concerns, whether the industries will be able to keep any competitive edge.

\section{Alternative Development Scenarios}

Energy concerns and stakeholder perceptions indicate that alternatives to solely industrial growth models do exist. For example, a switch to a free-market, capitalist system may leave residents free to assume more traditional economic structures, such as indigenous crafts, reindeer herding for meat production, ecotourism, and fishing expeditions within the many wilderness areas, specialized boat building, cultural tourism, and other pursuits. One potential conflict in this regard is that industrial growth, which degrades critical ecosystem services, may be incompatible with economic activities such as ecotourism and reindeer herding that depend on those services. While some indigenous Siberian groups have been successful at combining newer and more traditional economic activities to reduce their dependency on the global economy, others have fallen into poverty (Ziker, 1998). Analysis within the PIA is required to learn whether there are multiple strategies that local residents can employ to achieve economic self-sufficiency, or if there is a single adaptive strategy for transitioning to new economic systems.

Another possible development scenario has recently emerged that may balance energy concerns and stakeholder perceptions by exploiting the established physical and educational infrastructure of the region. Specifically, hightech companies may be coming in to use the large, welleducated labor force of the Kola Peninsula, importing production equipment and training Kola personnel abroad. The operating costs of such ventures in the Kola Peninsula, including transport costs, are only $45 \%$ of what they would be in Sweden, for example (George, 2002). With high unemployment and economic uncertainty currently the norm in the Kola region, this alternative development path would be a welcome relief for local residents.

\section{CONCLUSIONS}

By applying the PIA approach, the pilot project has established relationships with local scientists and stakeholders while learning critical lessons for subsequent work. We have also identified a number of issues that require more detailed research. One such issue is valuation of ecosystem services. As the Kola Peninsula increasingly relies on the market mechanism to allocate its scarce resources, it confronts the same three general problems as the rest of the planet in this regard. First, it is very unclear how ecosystems generate their valuable services, as they are emergent properties of complex systems. Little is known of how ecosystem structure generates these functions or how humans affect them. Second, many elements of ecosystem structure, such as trees and fish, are market goods, and their exploitation generates direct returns to whoever controls them-a powerful incentive for exploitation. In contrast, ecosystem services are non-excludable, non-market goods, and markets do not provide incentives for protecting them. In the absence of market incentives, other institutions, such as government, must create the incentives (through education, regulation, legislation, taxes) for preserving these services. Yet ecosystem services provide different levels of benefits to society at the local, regional, national, and global scales, and activities that degrade ecosystems and their services impose different costs at different scales. A third problem, therefore, is that incentives for preserving these ecosystem services will differ between scales. There is a major need to increase the understanding of how ecosystem structure generates services in the Arctic system, who benefits from these services, and what government policies at different 
administrative levels can provide incentives for the adequate protection of these services.

The whole question of sustainability is difficult to pose for this particular region. For example, when economists talk about sustainability, they are still usually implying stable economic growth. This view is further enhanced by the Russian translation of sustainable development as "stable development." The notion of stable economic development is easily substituted by the idea of stable growth, which is quite opposite to the Western idea of sustainable development as a steady-state, zero-growth economy (Daly, 1977). Yet it should be understood that the zero-growth concept is a "hard sell" under the conditions of social despair and economic degradation that have prevailed in the Kola North for the last decade. Also, systems in transition in the former Soviet Union may not be interested in sustainable solutions, because by definition they are undergoing change rather than maintenance. According to Holling's (1992) classification, these systems are either in the release or renewal stages, which one would hardly want to sustain, or they have just entered the growth stage, when it is still hard to start thinking in terms of steady-state economy (Daly, 1977) and sustainability. Economic transition assumes large shifts in social and political institutions. In the presence of such shifts, adjustments are usually made possible because the majority of the population is discontent and rejects the status quo, whereas sustainability is based on social contentment and agreement (Voinov, 1998). Given this uncertainty, it makes more sense to be concerned with the design of adaptive management strategies that enable sustainable development in the future.

Most of these issues spread across disciplinary boundaries, which makes it hard to investigate the issues within the format of conventional disciplinary studies. The PIA itself provides a frame of reference for further study. We need to develop this framework significantly to better understand and value local resources and to increase its utility for decision making. At present there are certainly more open questions than answers available. The project has built an international and cross-disciplinary team of researchers who have learned to communicate ideas across borders and disciplines. Data sets have been assembled, and major model hypotheses have been formulated, while continued interaction with the stakeholders will help ensure their future involvement in the research process and its results.

\section{ACKNOWLEDGEMENTS}

The work was supported by a grant from the NSF Office of Polar Programs OPP 0095196. Our thanks are due to Alexander Perlikov for all his assistance and help; Tatiana Alieva, who helped assemble the results of the survey; Ilya Mikhailov, who assisted with compiling economic data sets; Oksana Vandysh, who was crucial in organizing workshops and travel; and Sergei Sandimirov and Galina Kudryavtseva, who assembled all the biochemical data. We wish to acknowledge valuable ideas and advice contributed by Robert Wheelersburg, Vladimir Masloboyev, John Hobbie, Louis Codispoti, JoLynn Carroll, Nikolay Kashulin, Vladimir Dauvalter, Boris Ilyashuk, Vitaly Lystsov, and Gennadii Kalabin. We are grateful to many anonymous researchers, decision makers, and citizens who attended our workshops and helped us understand the system. Many thanks to Henry Huntington and three anonymous reviewers for their useful comments and suggestions.

\section{REFERENCES}

AMAP (ARCTIC MONITORING AND ASSESSMENT PROGRAMME). 1998. AMAP Assessment Report: Arctic pollution issues. Oslo, Norway: AMAP.

ARMSTRONG, T. 1965. Russian settlements in the North. Cambridge: Cambridge University Press.

BERNSHTAM, T.A. 1984. Pomors and their significance for the historical and cultural processes in Russia. In: Belogubova, N.N., and Trumenkov, G., eds. The role of Archangelsk in the economic development of the North. Archangelsk: Archangelsk Department of the Geographical Society of the USSR. 9-11.

BLUMENTHAL, D., and JANNINK, J.L. 2000. A classification of collaborative management methods. Conservation Ecology 4(2):13-20. <www.consecol.org/Journal/vol4/iss2/art13>

COSTANZA, R. 1996. Ecological economics: Reintegrating the study of humans and nature. Ecological Applications 6(4): 978-990.

COSTANZA, R., and RUTH, M. 1998. Using dynamic modeling to scope environmental problems and build consensus. Environmental Management 22(2):183-195.

COSTANZA, R., D'ARGE, R., DE GROOT, R., FARBERK, S., GRASSO, M., HANNON, B., LIMBURG, K., NAEEM, S., O'NEILL, R.V., PARUELO, J., RASKIN, R.G., SUTTON, P., and VAN DEN BELT, M.1997. The value of the world's ecosystem services and natural capital. Nature (May 15) 387:253-260.

COSTANZA, R., VOINOV, A., BOUMANS, R., MAXWELL, T., VILLA, F., VOINOV, H., and WAINGER, L. 2002. Integrated ecological economic modeling of the Patuxent river watershed, Maryland. Ecological Monographs 72(2):203-231.

DALY, H. 1977. Steady-state economics. San Francisco: W.H. Freeman.

FUNTOWICZ, S.O., and RAVETZ, J.R. 1993. Science for the post-normal age. Futures 25(7):739-755.

1994. Emergent complex systems. Futures 26(6): $568-582$.

GEORGE, N. 2002. Westernising the far North: Low costs may not be enough to keep the Barents region alive. Financial Times (London), July 22.

GOMA, H.C., RAHIM, K., NANGENDO, G., RILEY, J., and STEIN, A. 2001. Participatory studies for agro-ecosystem evaluation. Agriculture, Ecosystems \& Environment 87(2):179-190.

HOLLING, C.S. 1992. Cross-scale morphology, geometry, and dynamics of ecosystems. Ecological Monographs 62(4): 447-502.

INEP (INSTITUTE OF NORTH INDUSTRIAL ECOLOGY PROBLEMS). 1999. Ecological atlas of the Murmansk Oblast 
(Ecologicheskii atlas Murmanskoi oblasti). In Russian. Edited by Vishniakov, I.A., Kalabin, G.B., Makarova, T.D., Tikunov, V.S., Evdokimova, G.A., Evseev, A.V., Kotova, T.V., Kochkurkin, A.F., Krasovskaya, T.M., Matishev, G.G., Moiseenko, T.I., Hikonov, V.V., and Semenov, A.V. Moscow and Apatity: Kola Science Center. 48 p.

KEMMIS, S., and McTAGGART, R., eds. 1998. The action research planner. 3rd ed. Victoria, Australia: Deakin University.

KRASOVSKAYA, T.M. 1998. Cultural landscape of far-northern regions of Russia as a basis for sustainable development. (Kulturnii landshaft raionov krainego severa Rossii kak osnova ustoichivogo razvitiya regiona). In: Cultural landscape: Problems of theory and research methodology (Kulturnii landshaft: voprosi teorii I metodologii issledovanii). In Russian. Smolensk: Smolensk State University. 45-71.

2002. The early period of the Kola Peninsula and the Imandra Watershed development. Proceedings of the International Conference on the Ecology of Northern Territories of Russia. In Russian. Archangelsk: Institute of Ecological Problems of the North, Ural Branch of the Russian Academy of Sciences. Vol. 2:789-793.

LANDSCAN. 2001. Global population database. Oak Ridge, Tennessee: Oak Ridge National Laboratory. Available at http:/ /www.ornl.gov/gist/.

LOPEZ-RIDAURA, S., MASERA, O., and ASTIER, M. 2002. Evaluating the sustainability of complex socio-environmental systems. The MESMIS framework. Ecological Indicators 2 $(1-2): 135-148$.

LUKYACHENKO, T.B. 1994. Saami. In: Peoples of Russia. Moscow: Bolshaya Rossiiskaia Encyclopedia. 310-312.

LUZIN, G.P., PRETES, M., and VISSLIEV, V. 1994. The Kola Peninsula: Geography, history, and resources. Arctic 47(1):1-15.

LUZIN, G.P., SELIN, V.S., and KORCHAK, A.D. 1998. Living standards in the Kola North (Uroven' zhizni na severe). In Russian. Apatity: INEP.

LUZIN, G.P., SELIN, V.S., VERBINENKO, E., DIDYK, V., and PAVLOVA, S. 1999. Stability and economic security in regions: Trends, criteria, regulation mechanisms (Ustoichvost' i economicheskaya bezopasnost' regionov: trendi, kriterii, mekhanizmi regulirovaniya). In Russian. Apatity: Kola Science Center. 174 p.

MARTELLO, M.L. 2001. A paradox of virtue?: “Other” knowledges and environment-development politics. Global Environmental Politics 1(3):114-141.

MENDOZA, G.A., and PRABHU, R. 2000. Development of a methodology for selecting criteria and indicators of sustainable forest management: A case study on participatory assessment. Environmental Management 26(6):659-673.

MOISEENKO, T. 2000. The Imandra Lake watershed: The contradictions of ecological and economic interests. Presentation at the 2000 AAAS Annual Meeting, 17-22 February 2000, Washington, D.C.

- 2002. Anthropogenic modification of the Lake Imandra ecosystem (Antropogenniye modifikatsii ecosistemi ozera Imandra). In Russian. Moscow: Nauka. 378 p.

MOISEENKO, T., and YAKOVLEV, V.A. 1990. Anthropogenic transformations in aquatic systems of the Kola North
(Antropogennye preobrozovaniya vodnikh ecosystem Kolskogo severa). In Russian. Leningrad: Nauka. 217 p.

MOISEENKO, T., KUDRYAVTSEVA, L., RODYUSHKIN, I., DAUVALTER, V., LUKIN, A., and KASHULIN, N. 1995. Airborne contamination by heavy metals and aluminum in the freshwater ecosystems of the Kola subarctic region. In Russian. The Science of the Total Environment 160-161:715-727.

MÜLLER-WILLE, L., and HUKKINEN, J. 1999. Human environmental interactions in Upper Lapland, Finland: Development of participatory research strategies. Acta Borealia 2:43-47.

MYAGKOV, C.M. 1976. Natural environment of the Khibiny training center. Moscow: Moscow State University.

NEFCO (NORDIC ENVIRONMENTAL FINANCE CORPORATION). 1995. Proposals for environmentally sound investment projects in the Russian part of the Barents Region, Vols. I and II. Oslo: AMAP Expert Group.

PRAVDA. 2001. Russia, World Bank launch programme to readjust Northerners in warmer parts of Russia. July 11.

RZEVSKY, B.N. 1997. Dictionary of Saami geographical terms of the Khibiny. Kirovsk: Golos Prirody. 27 p.

SEPPELT, R., and VOINOV, A. 2002. Optimization methodology for land use patterns using spatially explicit landscape models. Ecological Modelling 151(2-3):125-142.

USHAKOV, I.F. 1984. Pomor of Murmansk. In: Belogubova, N.N., and Trumenkov, G., eds. The role of Archangelsk in the economic development of the North. Archangelsk: Archangelsk Department of the Geographical Society of the USSR. 37-39.

VAN ASSELT, M.B.A., ROTMANS, J., and GREEUW, S. 2001. Puzzle-solving for policy: A provisional handbook for integrated assessment. Maastricht, The Netherlands: International Centre for Integrative Studies.

VAN DEN BELT, M. 2004. Mediated modeling: A systems dynamics approach to environmental consensus building. Washington, D.C.: Island Press. 340 p.

VOINOV, A. 1998. Paradoxes of sustainability. Journal of General Biology 59:209-218.

VOINOV, A., and COSTANZA, R. 1999. Watershed management and the web. Journal of Ecosystem Management 56:231-245.

VOINOV, A.A., FITZ, C.H., and COSTANZA, R. 1998. Surface water flow in landscape models: 1. Everglades case study. Ecological Modelling 108:131-144.

VOINOV, A., VOINOV, H., and COSTANZA, R. 1999a. Surface water flow in landscape models: 2. Patuxent watershed case study. Ecological Modelling 119(2-3):211-230.

VOINOV, A., COSTANZA, R., WAINGER, L., BOUMANS, R., VILLA, F., MAXWELL, T., and VOINOV, H. 1999b. Patuxent landscape model: Integrated ecological economic modeling of a watershed. Journal of Environmental Modelling and Software 14:473-491.

WADSWORTH, Y. 1998. What is participatory action research? Action Research International, Paper 2. Available on-line: http:/ /www.scu.edu.au/schools/gcm/ar/ari/p-ywadsworth98.html

WEBLER, T., TULER, S., and KRUEGER, R. 2001. What is a good public participation process? Five perspectives from the public. Environmental Management 27(3):435-450.

ZIKER, J. 1998. Land tenure and economic collapse in northern Siberia. Arctic Research of the United States 12:73-80. 